\title{
The Genome Sequence of a Type ST239 Methicillin-Resistant Staphylococcus aureus Isolate from a Malaysian Hospital
}

\author{
LS Lee ${ }^{1,2}$, LK Teh ${ }^{1}$, ZF Zainuddin² and MZ Salleh ${ }^{1 *}$ \\ ${ }^{1}$ Integrative Pharmacogenomics Centre, Faculty of Pharmacy, Universiti Teknologi MARA \\ Malaysia, 42300 Bandar Puncak Alam, Selangor, Malaysia. \\ ${ }^{2}$ School of Health Sciences, Universiti Sains Malaysia, 16150 Kubang Kerian, Kelantan, Ma- \\ laysia \\ *Corresponding author: MZ Salleh (zakisalleh.mzs@gmail.com)
}

Keywords: Staphylococcus aureus, MRSA, Malaysia, Genomics

We report the genome sequence of a healthcare-associated MRSA type ST239 clone isolated from a patient with septicemia in Malaysia. This clone typifies the characteristics of ST239 lineage, including resistance to multiple antibiotics and antiseptics.

\section{Introduction}

Antibiotic resistance in $S$. aureus is a major concern, as an increasing number of infections are caused by methicillin-resistant $S$. aureus (MRSA). Figure 1 shows the phylogenetic position of $S$. aureus in relation to other staphylococci. In Malaysia, the incidence of MRSA-related infections is a cause of concern in hospitals country-wide. Health-associated MRSA (HA-MRSA) has been dominated by a few lineages in Southeast Asia, particularly ST239. Sequence type 239 is an international healthcare-associated (HA) MRSA lineage prevalent in Asia, South America and Eastern Europe, which includes EMRSA-1, $-4,-7$, and -11 and the Brazilian, Portuguese, Hungarian, and Viennese clones. Strains of type ST239 are typically resistant to multiple classes of antibiotics and antiseptics such as $\beta$-lactam antibiotics.

\section{Classification and features}

We have chosen a representative of an MRSA strain, termed MRSA PR01 isolated from a patient with septicemia, isolated from a hospital in Kuala Lumpur. Table 1 indicates general information gathered on MRSA PR01. The MRSA PR01 strain has been identified as sequence type 239 (ST239) by multilocus sequence typing (MLST). Initial disc susceptibility tests showed that the strain is resistant to $\beta$-lactam antibiotics oxacillin, ampicillin, cefuroxime, ceftriaxone, gentamicin, erythromy- cin, ciprofloxacin and co-trimoxazole.

\section{Genome sequencing information Genome project history}

This organism was selected for sequencing as a representative of MRSA infection in a local Malaysian hospital. The genome sequences of this organism were deposited in GenBank (WGS database). Sequencing, finishing and annotation were performed at the Pharmacogenomics Centre (PROMISE), UiTM. Table 2 presents the project information and its association with MIGS version 2.0 compliance [14].

\section{Growth conditions and DNA isolation}

MRSA PR01 was grown overnight under aerobic conditions in Tryptic Soy Broth at $37^{\circ} \mathrm{C}$. DNA extraction was performed using MasterPure ${ }^{\mathrm{TM}}$ Gram Positive DNA Purification Kit (Epicentre, Madison, USA) as per manufacturer's instructions. The concentration and purity of resultant DNA was assessed by UV spectrophotometry (Nanodrop, Thermo Scientific). $5 \mu$ g of genomic DNA $\left(A_{260 / 280}\right.$ $=1.88$ ) was used for library preparation.

\section{Genome sequencing and assembly}

The genome sequence was obtained using $104 \mathrm{Mb}$ of paired-end (300 bp spacing) data from the Illumina GAII $x$ platform (Illumina, San Diego, CA) with 36-bp reads. Sequence data were assembled using CLCBio Genomics Workbench (CLC bio, Aar- 
hus, Denmark). One hundred and ninety-five contigs (N50: 13,272 bp) were generated, and were overlaid with the reference sequence Mu50 using OSLay. Fourteen supercontigs were gener- ated as a result. Gaps were closed using Sanger sequencing.

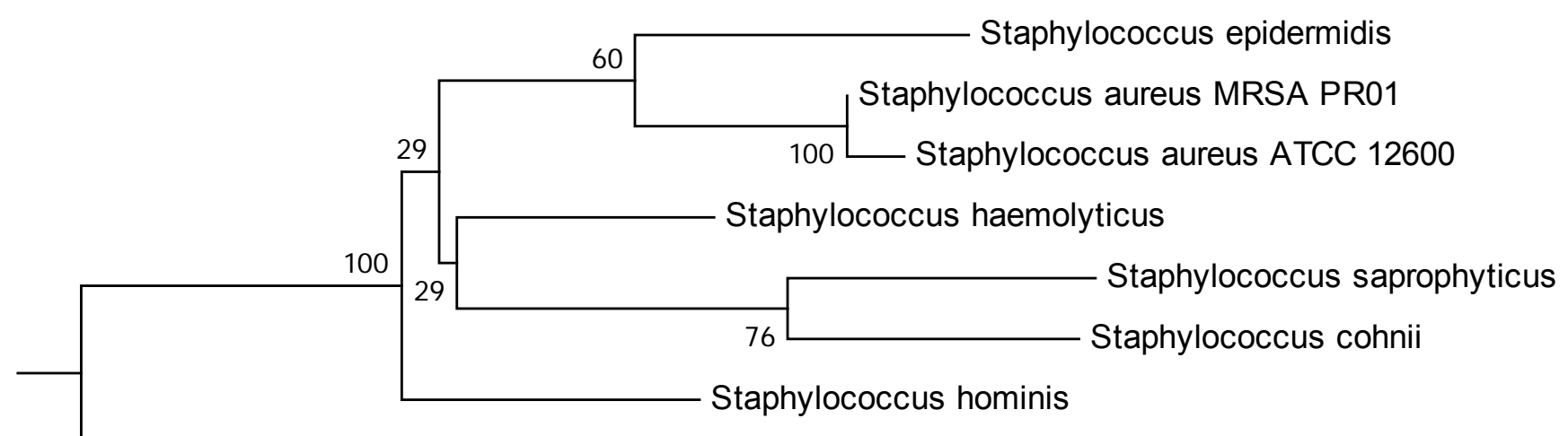

Staphylococcus lutrae

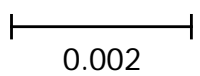

Figure 1. Phylogenetic tree highlighting the position of Staphylococcus aureus strain PR01 relative to other type strains within the Staphylococcaceae. The strains and their corresponding GenBank accession numbers for 16 S rRNA genes are: S. aureus strain ATCC 12600, L36472; S. saprophyticus strain ATCC 15305, AP008934; S. epidermidis strain ATCC 14990, D83363; S. hominis strain DSM 20328, X66101; S. haemolyticus strain CCM2737, X66100; and S. cohnii strain ATCC 49330, AB009936. The tree uses sequences aligned by the RDP aligner, and uses the Jukes-Cantor corrected distance model to construct a distance matrix based on alignment model positions without the use of alignment inserts, and uses a minimum comparable position of 200. The tree is built with RDP Tree Builder, which uses Weighbor [1] with an alphabet size of 4 and length size of 1000. The building of the tree also involves a bootstrapping process repeated 100 times to generate a majority consensus tree [2]. Staphylococcus lutrae (X84731) was used as an outgroup.

\section{Genome properties}

The MRSA PR01 genome consists of a 2,725,110bp circular chromosome with a GC content of $32.6 \%$ (Table 3). The MRSA PR01 genome contains 2668 CDs with 19 rRNA features (). A total of $1722(64.5 \%)$ of protein coding genes were assigned to COGs, and a breakdown of the functional assignment of COG-assigned genes is shown in Table 4. Plasmid sequences were only partially sequenced. Figure 2 depicts genomic regions of interest found in the preliminary analysis of the MRSA PR01 genome.

Initial analysis of the genome revealed several key features. This genome has a typical SCCmec type III cassette, containing cadmium resistance genes. SCCmec type III is a composite element that is comprised of SCCmec and SCCmercury. In the MRSA PR01 genome, like others, this region harbors $c c r C$, pI258 and Tn554 as well as the genes involved in cadmium resistance. The MRSA PR01 genome contains two pathogenicity islands, and several resistance features were identified such as the qacA gene, which confers resistance to antiseptics such as cationic biocides, quaternary ammonium salts, and diamidines via an exportmediated mechanism, and the norA gene which confers resistance to hydrophilic quinolones such as norfloxacin and ciprofloxacin. There were 9 regions defined as prophage regions by PHAST [17] with one complete prophage region.genes were identified in the genome. A total of 2,267 genes $(72.66 \%)$ were assigned a putative function. The remaining genes were annotated as hypothetical proteins. The properties and the statistics of the genome are summarized in Table 3 . The distribution of genes into COGs and KEGG functional categories is presented in Table 4 . 


\section{Conclusion}

This study is the first to report on the whole genome sequence of a Malaysian MRSA isolate. Preliminary analysis of the genome has highlighted the genetic determinants that are responsible for the organism to adapt easily to selective pressures. Further research is being conducted to pro- vide insight on the adaptive power of this healthcare-associated strain to attain high resistance to antibiotics.

Nucleotide sequence accession numbers. This Whole Genome Shotgun project has been deposited at DDBJ/EMBL/GenBank under the accession ANP000000000. The version described in this paper is the first version, ANPO01000000.

Table 1. Classification and general features of Staphylococcus aureus MRSA PR01

\begin{tabular}{|c|c|c|c|}
\hline MIGS ID & Property & Term & $\begin{array}{l}\text { Evidence } \\
\text { code }^{\mathrm{a}}\end{array}$ \\
\hline & Current classification & $\begin{array}{l}\text { Domain Bacteria } \\
\text { Phylum Firmicutes } \\
\text { Class Bacilli } \\
\text { Order Bacillales } \\
\text { Family Staphylococcaceae } \\
\text { Genus Staphylococcus } \\
\text { Species Staphylococcus aureus } \\
\text { Type strain MRSA PR01 }\end{array}$ & $\begin{array}{l}{[3]} \\
{[4-7]} \\
{[8,9]} \\
{[6,10]} \\
{[9,11]} \\
{[6,12]} \\
{[6,12]} \\
\text { TAS }\end{array}$ \\
\hline & Gram stain & Positive & TAS \\
\hline & Cell shape & Coccus & TAS \\
\hline & Motility & Non-motile & TAS \\
\hline & Sporulation & Non-sporulating & TAS \\
\hline & Temperature range & Mesophile & TAS \\
\hline & Optimum temperature & $30-37^{\circ} \mathrm{C}$ & TAS \\
\hline & Carbon source & Glucose & TAS \\
\hline & $\begin{array}{l}\text { Energy source } \\
\text { Terminal electron re- } \\
\text { ceptor }\end{array}$ & Chemoorganotrophic & \\
\hline MIGS-6 & $\begin{array}{l}\text { Habitat } \\
\text { Salinity }\end{array}$ & Human respiratory tract, skin & TAS \\
\hline MIGS-22 & Oxygen & Facultative anaerobe & TAS \\
\hline MIGS-15 & Biotic relationship & & \\
\hline MIGS-14 & Pathogenicity & Opportunistic pathogen & TAS \\
\hline MIGS-4 & Geographic location & Malaysia & \\
\hline MIGS-5 & Sample collection time & May 2009 & \\
\hline MIGS-4.1 & Latitude & $4.1936^{\circ} \mathrm{N}$ & \\
\hline MIGS-4.2 & Longitude & $103.7249^{\circ} \mathrm{E}$ & \\
\hline MIGS-4.3 & Depth & Not reported & \\
\hline MIGS-4.4 & Altitude & Not reported & \\
\hline
\end{tabular}

aEvidence codes - TAS: Traceable Author Statement (i.e., a direct report exists in the literature). These evidence codes are from the Gene Ontology project [19]. 
Table 2. Project information

\begin{tabular}{lll}
\hline MIGS ID & Property & Term \\
\hline MIGS-31 & Finishing quality & Non-contiguous Finished \\
MIGS-28 & Libraries used & One 350bp Illumina GAllx genomic library \\
MIGS-31.2 & Fold coverage & Illumina GAllx, Sanger \\
MIGS-30 & Assemblers & CLCBio Genomics Workbench \\
MIGS-32 & Gene calling method & Glimmer and GeneMark \\
& Genbank ID & ANPO01000000 \\
& Genbank Date of Release & January 11, 2014 \\
& GOLD ID & Gi0037576 \\
MIGS-13 & Project relevance & Medical, Tree of life \\
\hline
\end{tabular}

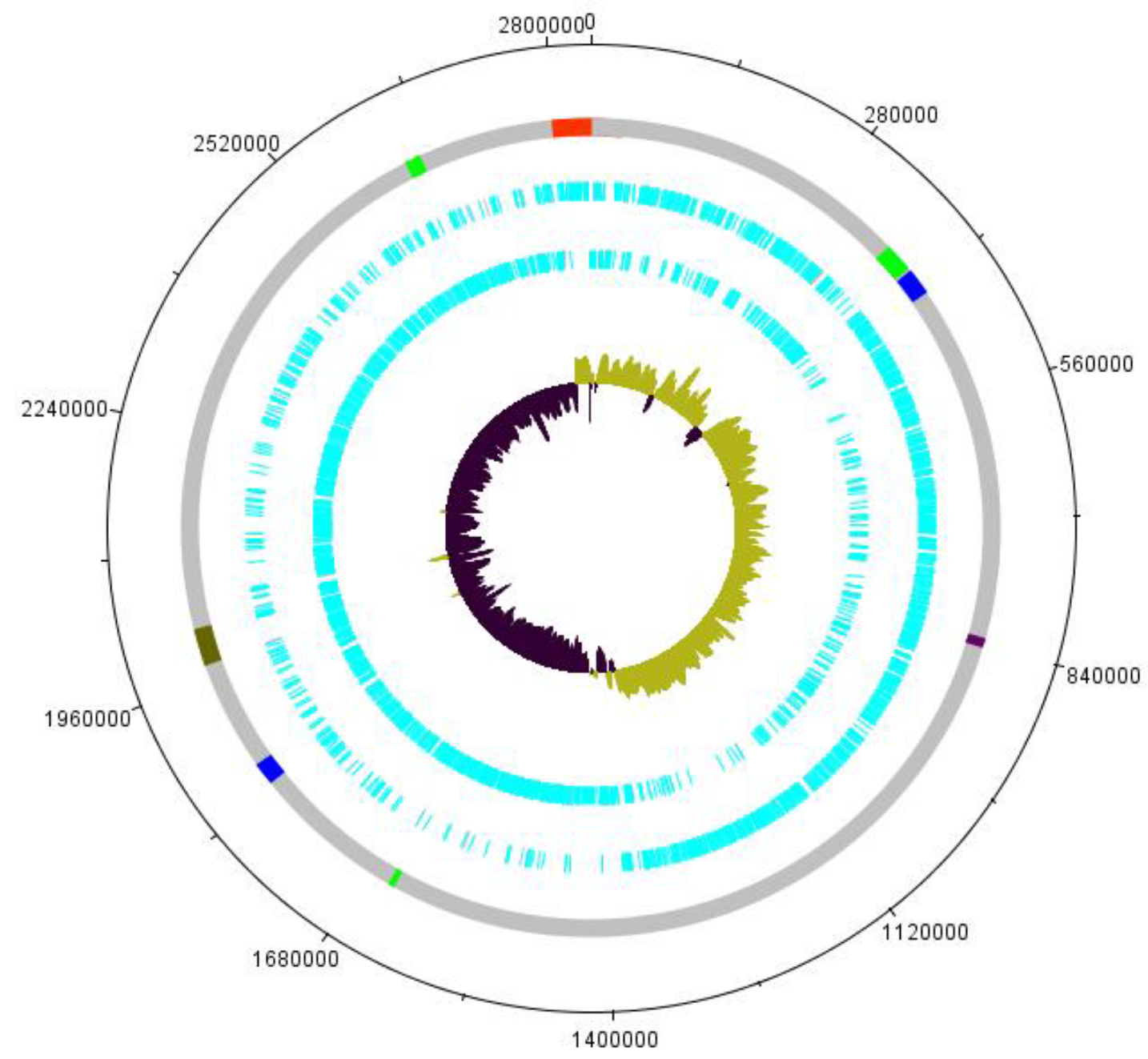

Figure 2. Visual representation of the MRSA PR01 genome. From outer to inner tracks: Scale (in bases); annotated CDSs colored according to predicted function (red, SCC element; blue, genomic island; green, transposon/ integrative conjugative element; purple, $S$. aureus pathogenicity island [SaPI], brown, prophage); forward strand CDS; reverse strand CDS; GC skew. 
Table 3. Nucleotide content and gene count levels of the MRSA PR01 genome

\begin{tabular}{lrr}
\hline Attribute & Value & \% $_{\text {of }}$ total $^{\mathbf{a}}$ \\
\hline Genome size (bp) & $2,725,110$ & 100 \\
DNA G+C content $(b p)$ & 888,386 & 32.6 \\
DNA Coding region $(b p)$ & $2,555,544$ & 90.03 \\
Total genes & 2687 & 100 \\
RNA genes & 19 & 0.7 \\
Protein-coding genes & 2668 & 99.3 \\
Genes with protein function prediction & 2,267 & 72.66 \\
Genes assigned to COGs & 1722 & 64.5 \\
\hline
\end{tabular}

${ }^{a}$ The total is based on either the size of the genome in base pairs or the total number of protein coding genes in the annotated genome

Table 4. Number of genes associated with the 25 general COG functional categories

\begin{tabular}{|c|c|c|c|}
\hline Code & Value & $\%$ age $^{a}$ & Description \\
\hline$J$ & 140 & 5.247 & Translation \\
\hline A & - & - & RNA processing and modification \\
\hline K & 127 & 4.760 & Transcription \\
\hline $\mathrm{L}$ & 126 & 4.723 & Replication, recombination and repair \\
\hline B & - & - & Chromatin structure and dynamics \\
\hline $\mathrm{D}$ & 23 & 0.862 & Cell cycle control, mitosis and meiosis \\
\hline Y & - & - & Nuclear structure \\
\hline V & - & - & Defense mechanisms \\
\hline $\mathrm{T}$ & 47 & 1.762 & Signal transduction mechanisms \\
\hline M & 91 & 3.411 & Cell wall/membrane biogenesis \\
\hline $\mathrm{N}$ & 4 & 0.150 & Cell motility \\
\hline Z & 0 & 0 & Cytoskeleton \\
\hline W & 0 & 0 & Extracellular structures \\
\hline$U$ & 0 & 0 & Intracellular trafficking and secretion \\
\hline $\mathrm{O}$ & 72 & 2.699 & $\begin{array}{l}\text { Posttranslational modification, protein turnover, } \\
\text { chaperones }\end{array}$ \\
\hline $\mathrm{C}$ & 106 & 3.973 & Energy production and conversion \\
\hline G & 129 & 4.835 & Carbohydrate transport and metabolism \\
\hline $\mathrm{E}$ & 186 & 6.972 & Amino acid transport and metabolism \\
\hline $\mathrm{F}$ & 68 & 2.549 & Nucleotide transport and metabolism \\
\hline $\mathrm{H}$ & 83 & 3.111 & Coenzyme transport and metabolism \\
\hline I & 62 & 2.324 & Lipid transport and metabolism \\
\hline$P$ & 123 & 4.610 & Inorganic ion transport and metabolism \\
\hline Q & 23 & 0.862 & $\begin{array}{l}\text { Secondary metabolites biosynthesis, transport and ca- } \\
\text { tabolism }\end{array}$ \\
\hline $\mathrm{R}$ & 193 & 7.234 & General function prediction only \\
\hline $\mathrm{S}$ & 119 & $\begin{array}{l}4.460 \\
35.45\end{array}$ & Function unknown \\
\hline- & 946 & 7 & Not in COGs \\
\hline
\end{tabular}

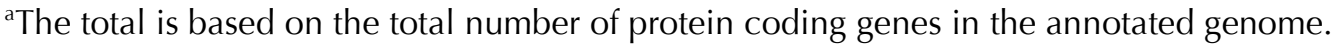




\section{Conclusion}

\section{Description of Sulfurimonas hongkongensis sp. nov.}

Sulfurimonas hongkongensis (hong.kong.en'sis. N.L. fem. adj. hongkongensis pertaining to Hong Kong, the city where the type strain was isolated).

Strain AST-10T is rod-shaped with size of $0.2-0.4$ $\mu \mathrm{m} \times 0.5-1.2 \mu \mathrm{m}$. It is an obligate anaerobe and occurs singly. The temperature range for growth is $15-35^{\circ} \mathrm{C}$, optimum at $30^{\circ} \mathrm{C}$. The $\mathrm{pH}$ range for growth is 6.5-8.5, optimum at 7.0-7.5. The salinity range for growth is $10-60 \mathrm{~g} \mathrm{~L}^{-1}$, and optimum at 30 $\mathrm{g} \mathrm{L}^{-1}$. Strictly chemolithoautotrophic growth occurs with $\mathrm{H}_{2}$, HS- or $\mathrm{S}_{2} \mathrm{O}_{3}{ }^{2-}$ as an electron donor and with nitrate as an electron acceptor. Nitrate is reduced to $\mathrm{N}_{2}$, and reduced sulfur compounds are oxidized into $\mathrm{S}^{0}$ or $\mathrm{SO}_{4}{ }^{2-}$ (depending on molar ratio of $\mathrm{S}_{2} \mathrm{O}_{3}{ }^{2-} / \mathrm{NO}_{3}{ }^{-}$). The major cellular fatty acids are $\mathrm{C}_{14: 0}, \mathrm{C}_{16: 0}, 2-\mathrm{OH} \mathrm{C}_{16: 0}, \mathrm{C}_{16: 1}, \mathrm{C}_{18: 0}$, and $\mathrm{C}_{18: 1}$, with $\mathrm{C}_{16: 0}$ 2-о $\mathrm{OH}$ a unique fatty acid different from other species in the genus Sulfurimonas.

The type strain AST $-10^{\mathrm{T}}=$ DSM $2096^{\mathrm{T}}=\mathrm{JCM}$ $18418^{\mathrm{T}}$, was isolated from coastal sediment at the Kai Tak Approach Channel connected to Victoria Harbour in Hong Kong, China. The GC content of the genome is $34.9 \%$. The genome sequence has been deposited at DDBJ/EMBL/GenBank under accession number AUPZ00000000.

\section{Acknowledgments}

Dr. Lin Cai thanks The University of Hong Kong for the Postdoctoral Fellowship. This study was financially supported by the Research Grants Council of Hong Kong (HKU7201/11E).

\section{References}

1. Inagaki F, Takai K, Kobayashi $\mathrm{H}$, Nealson $\mathrm{KH}$, Horikoshi K. Sulfurimonas autotrophica gen. nov., sp. nov., a novel sulfur-oxidizing epsilonproteobacterium isolated from hydrothermal sediments in the Mid-Okinawa Trough. Int J Syst Evol Microbiol 2003; 53:1801-1805. PubMed http://dx.doi.org/10.1099/ijs.0.02682-0

2. Takai K, Suzuki M, Nakagawa S, Miyazaki M, Suzuki Y, Inagaki F, Horikoshi K. Sulfurimonas paralvinellae sp. nov., a novel mesophilic, hydrogen- and sulfur-oxidizing chemolithoautotroph within the Epsilonproteobacteria isolated from a deep-sea hydrothermal vent polychaete nest, reclassification of Thiomicrospira denitrificans as
Sulfurimonas denitrificans comb. nov. and emended description of the genus Sulfurimonas. Int J Syst Evol Microbiol 2006; 56:1725-1733. PubMed http://dx.doi.org/10.1099/ijs.0.64255-0

3. Labrenz M, Grote J, Mammitzsch K, Boschker HT, Laue $M$, Jost $G$, Glaubitz S, Jurgens $K$.

Sulfurimonas gotlandica sp. nov., a chemoautotrophic and psychrotolerant epsilonproteobacterium isolated from a pelagic Baltic Sea redoxcline, and an emended description of the genus Sulfurimonas. Int I Syst Evol Microbiol 2013; 63:4141-4148. PubMed http://dx.doi.org/10.1099/ijs.0.048827-0

4. Grote J, Schott T, Bruckner CG, Glockner FO, Jost G, Teeling H, Labrenz M, Jurgens K. Genome and physiology of a model Epsilonproteobacterium responsible for sulfide detoxification in marine oxygen depletion zones. Proc Natl Acad Sci USA 2012; 109:506-510. PubMed http://dx.doi.org/10.1073/pnas.1111262109

5. Sievert SM, Scott KM, Klotz MG, Chain PS, Hauser LJ, Hemp J, Hugler M, Land M, Lapidus A, Larimer FW, et al. Genome of the epsilonproteobacterial chemolithoautotroph Sulfurimonas denitrificans. Appl Environ Microbiol 2008; 74:1145-1156. PubMed

http://dx.doi.org/10.1128/AEM.01844-07

6. Sikorski J, Munk C, Lapidus A, Ngatchou Djao OD, Lucas S, Glavina Del Rio T, Nolan M, Tice $\mathrm{H}$, Han C, Cheng JF, et al. Complete genome sequence of Sulfurimonas autotrophica type strain (OK10). Stand Genomic Sci 2010; 3:194-202. PubMed

7. Bruckner CG, Mammitzsch K, Jost G, Wendt J, Labrenz M, Jurgens K. Chemolithoautotrophic denitrification of Epsilonproteobacteria in marine pelagic redox gradients. Environ Microbiol 2013; 15:1505-1513. PubMed http://dx.doi.org/10.1111/j.14622920.2012.02880.x

8. Shao M, Zhang T, Fang $\mathrm{HH}$. Autotrophic denitrification and its effect on metal speciation during marine sediment remediation. Water Res 2009; 43:2961-2968. PubMed http://dx.doi.org/10.1016/j.watres.2009.04.016

9. Zhang M, Zhang T, Shao MF, Fang HH. Autotrophic denitrification in nitrate-induced marine sediment remediation and Sulfurimonas denitrificans-like bacteria. Chemosphere 2009; 76:677-682. PubMed http://dx.doi.org/10.1016/j.chemosphere.2009.03. $\underline{066}$

10. Shao MF, Zhang T, Fang HH, Li X. The effect of nitrate concentration on sulfide-driven autotrophic denitrification in marine sediment. Chemosphere $2011 ; \mathbf{8 3}: 1-6$. PubMed 
http://dx.doi.org/10.1016/j.chemosphere.2011.01. $\underline{042}$

11. Field D, Garrity G, Gray T, Morrison N, Selengut J, Sterk P, Tatusova T, Thomson N, Allen MJ, Angiuoli SV, et al. The minimum information about a genome sequence (MIGS) specification. Nat Biotechnol 2008; 26:541-547. PubMed http://dx.doi.org/10.1038/nbt1360

12. Woese CR, Kandler O, Wheelis ML. Towards a natural system of organisms: proposal for the domains Archaea, Bacteria, and Eucarya. Proc Natl Acad Sci USA 1990; 87:4576-4579. PubMed http://dx.doi.org/10.1073/pnas.87.12.4576

13. Garrity GM, Bell JA, Lilburn T. Phylum XIV. Proteobacteria phyl. nov. In: Garrity GM, Brenner DJ, Krieg NR, Staley JT (eds), Bergey's Manual of Systematic Bacteriology, Second Edition, Volume 2, Part B, Springer, New York, 2005, p. 1.

14. Validation List No. 107. List of new names and new combinations previously effectively, but not validly, published. Int / Syst Evol Microbiol 2006; 56:1-6. PubMed http://dx.doi.org/10.1099/ijs.0.64188-0

15. Garrity GM, Bell JA, Lilburn T. Class V. Epsilonproteobacteria class. nov. In: Garrity GM, Brenner DJ, Krieg NR, Staley JT (eds), Bergey's Manual of Systematic Bacteriology, Second Edition, Volume 2, Part C, Springer, New York, 2005, p. 1145.

16. Garrity GM, Bell JA, Lilburn T. Order I. Campylobacterales ord. nov. In: Garrity GM, Brenner DJ, Krieg NR, Staley JT (eds), Bergey's Manual of Systematic Bacteriology, Second Edition, Volume 2, Part C, Springer, New York, 2005, p. 1145.

17. Garrity GM, Bell JA, Lilburn T. Family II. Helicobacteraceae fam. nov. In: Garrity GM, Brenner DJ, Krieg NR, Staley JT (eds), Bergey's Manual of Systematic Bacteriology, Second Edition, Volume 2, Part C, Springer, New York, 2005, p. 1168.

18. Ashburner M, Ball CA, Blake JA, Botstein D, Butler $\mathrm{H}$, Cherry JM, Davis AP, Dolinski K, Dwight SS, Eppig JT, et al. Gene ontology: tool for the unification of biology. Nat Genet 2000; 25:25-29. PubMed http://dx.doi.org/10.1038/75556

19. Stackebrandt E, Goebel BM. A Place for DNADNA Reassociation and 16s Ribosomal-RNA Se-
quence-Analysis in the Present Species Definition in Bacteriology. Int J Syst Bacteriol 1994; 44:846849. http://dx.doi.org/10.1099/00207713-44-4$\underline{846}$

20. RossellóoMora R. Amann R. The species concept for prokaryotes. FEMS Microbiol Rev 2001; 25:3967. PubMed http://dx.doi.org/10.1016/S01686445(00)00040-1

21. Gevertz D, Telang AJ, Voordouw G, Jenneman GE. Isolation and characterization of strains CVO and FWKO B, two novel nitrate-reducing, sulfideoxidizing bacteria isolated from oil field brine. Appl Environ Microbiol 2000; 66:2491-2501. PubMed http://dx.doi.org/10.1128/AEM.66.6.2491$\underline{2501.2000}$

22. Tatusov RL, Galperin MY, Natale DA, Koonin EV. The COG database: a tool for genome-scale analysis of protein functions and evolution. Nucleic Acids Res 2000; 28:33-36. PubMed http://dx.doi.org/10.1093/nar/28.1.33

23. Wu S, Zhu Z, Fu L, Niu B, Li W. WebMGA: a customizable web server for fast metagenomic sequence analysis. BMC Genomics 2011; 12:444. PubMed http://dx.doi.org/10.1186/1471-2164-12$\underline{444}$

24. Finn RD, Clements J, Eddy SR. HMMER web server: interactive sequence similarity searching. $\mathrm{Nu}$ cleic Acids Res 2011; 39:W29-W37. PubMed http://dx.doi.org/10.1093/nar/gkr367

25. Punta M, Coggill PC, Eberhardt RY, Mistry J, Tate J, Boursnell C, Pang N, Forslund K, Ceric G, Clements J, et al. The Pfam protein families database. Nucleic Acids Res 2012; 40:D290-D301. PubMed http://dx.doi.org/10.1093/nar/gkr1065

26. Petersen TN, Brunak S, von Heijne G, Nielsen $H$. SignalP 4.0: discriminating signal peptides from transmembrane regions. Nat Methods 2011; 8:785-786. PubMed http://dx.doi.org/10.1038/nmeth.1701

27. Krogh A, Larsson B, von Heijne G, Sonnhammer EL. Predicting transmembrane protein topology with a hidden Markov model: application to complete genomes. J Mol Biol 2001; 305:567580. PubMed http://dx.doi.org/10.1006/jmbi.2000.4315 